\title{
Is Nuclear Energy the Solution?
}

\author{
Milton H. Saier • Jack T. Trevors
}

Published online: 19 December 2009

(C) The Author(s) 2009. This article is published with open access at Springerlink.com

On October 29th, 2009, one of us, (MHS) attended a lecture on "Nuclear Responsibility" on the University of California, San Diego campus. The speaker was Rochelle Becker, Executive Director of the Alliance for Nuclear Responsibility. The information presented was both revealing and upsetting and is documented extensively in a pamphlet entitled: "Why a Future for the Nuclear Industry Is Risky." These sources emphasized the problems that exist, especially in the USA. This editorial is based on these sources.

We should all know that: first, investments in nuclear power are risky as indicated by the fact that Wall Street has chosen to stay clear; second, nuclear power plants are stated terrorist targets and carry serious risks of their own; third, nuclear power will not reduce our dependencies on foreign energy as is sometimes claimed; fourth, nuclear-generated electricity does not compare favorably with electricity derived from either the combustion of fossil fuels or renewable sources such as wind, solar, geothermal,

\footnotetext{
M. H. Saier $(\bowtie)$

Division of Biological Sciences,

University of California at San Diego,

La Jolla, CA 92093-0116, USA

e-mail: msaier@ucsd.edu

J. T. Trevors

School of Environmental Sciences, University of Guelph, Guelph, ON, Canada N1G 2W1

e-mail: jtrevors@uoguelph.ca
}

wave, and tide, and finally, there is currently no good means of nuclear waste disposal, hence more environmental pollution.

\section{Is Nuclear Power a Good Investment?}

Promises of improved safety and performance are coupled with billions of dollars of subsidies. Nevertheless, claims that nuclear power is a necessary energy source for displacing greenhouse gases has not convinced investors. Wall Street is flat out not investing in new nuclear power plants because they do not believe that they will be safe profitable investments. In fact, as things stand, new nuclear power plants will not be cost competitive with other electricity-generating alternatives. For example, wind power and other renewable technologies, combined with energy efficiency and conservation can be more cost effective and can be deployed much sooner than new nuclear power plants. Building expensive nuclear plants will divert private and public investment from the cheaper and readily available renewable and energy efficiency options needed to protect our climate and humanity.

In competitive markets, new nuclear power plants will be bad investments. By contrast, worldwide private equity and venture capital investments in clean energy continue to grow. Worldwide annual investments in renewable energy capacity are now 
over 50 billion US dollars, and renewable energy markets continue to grow.

Why do investors have little or no incentives to back the construction of new nuclear power plants? The answers are multifaceted and complex.

- Nuclear construction cost estimates in the USA have been far less than final costs, by roughly 3-fold.

- Standard \& Poor's has stated that "given that construction would entail using new designs and technology, cost overruns are highly probable."

- The Department of Energy's (DOE's) Energy Information Administration has clearly and concisely stated that "new plants are not expected to be economical."

- A 2003 study by the Massachusetts Institute of Technology forecasted that costs would be substantially in excess of traditional means.

- Nuclear utilities have acknowledged that there are large economic risks associated with the operation of nuclear power plants.

\section{Are Nuclear Power Plants Potential Targets of Terrorism?}

In testimony before the Select Committee on Intelligence in the US Senate in February 2005, FBI director Robert S. Mueller stated that, "Another area we consider vulnerable and target rich is the energy sector, particularly nuclear power plants. Al-Qa'ida planner Khalid Sheikh Mohammed had nuclear power plants as part of his target set and we have no reason to believe that Al-Qa'ida has reconsidered."

Over 53,000 metric tons of highly radioactive spent nuclear fuel is stored at commercial reactors in the US. Nearly $90 \%$ of this fuel is stored in cooling pools without adequate protection. Does this sound like a pollution problem? According to a study by the National Academy of Sciences, a terrorist attack on a spent fuel pool could lead to the release of large quantities of radioactive materials to the environment. Such an event could result in thousands of cancer deaths and economic damages in the range of hundreds of billions of dollars.

In the event of a major radioactive release from a nuclear power plant, public opinion would likely react strongly against nuclear power (as occurred after the
Chernobyl and Three Mile Island accidents), resulting in the halting of construction of any new planned reactors.

\section{Will Nuclear Power Relieve our Dependency on Foreign Energy?}

The USA is importing more oil each year-most of it from the world's most unstable regions-increasing our country's economical and political vulnerability and making oil dependency among the largest threats to our economy and national security.

Nuclear power's only substantial contribution to oil displacement in the USA comes in regions in which natural gas, displaced by nuclear power, can penetrate further into oil's share of the markets, such as space heating in New England.

Indeed, transportation is the sector that accounts for most of USA oil consumption. About two thirds of the country's oil consumption is used by vehicles, which corresponds to roughly 13 million barrels per day. Thus, nuclear power development would not have an appreciable influence on these statistics.

To make matters worse, almost all of the uranium produced on the planet comes from foreign sources. Moreover, like oil, there is a limited supply, suggesting that if demand increases, so will the price. Money will continue to flow out of the USA without diminution.

\section{How does Nuclear Power Compare with Traditional and Renewable Energy Sources?}

Climate change is one of the most pressing threats of our time and it is imperative that we take swift and decisive action to avert its most severe impacts. However, building more nuclear power plants does not appear to provide an answer.

The claim that "we need all energy options" to face growing energy needs is irresponsible. In fact, we cannot afford all energy options. Further investment in nuclear power is likely to squander the limited financial resources that are available to implement meaningful climate change mitigation policies. Moreover, nuclear power plants are not $\mathrm{CO}_{2}$ free. Enriched uranium is the required fuel for all US nuclear power plants, and the uranium enrichment process emits 
about $15 \%$ of the $\mathrm{CO}_{2}$ emitted from a coal-fired power plant per unit of electrical energy.

Wind power and other renewables, such as solar and bio-energy, coupled with energy efficiency, and conservation are proving to be much more cost effective. Moreover, they can be deployed much faster. Building new nuclear power plants will divert private and public investment from the cheaper, readily available options needed to protect our global climate. Each dollar invested in electric efficiency in the USA displaces nearly seven times as much carbon dioxide as a dollar invested in nuclear power, and nuclear power saves as little as half as much carbon per dollar as wind power.

Recent studies analyzing the potential of nuclear power to combat global warming have concluded that between 1,000 and 2,000 new nuclear reactors would have to be built around the globe to achieve a meaningful impact on carbon dioxide emissions. These projections point to an infeasible schedule as new reactors would have to be completed every few weeks.

\section{How Are We to Dispose of Nuclear Waste?}

One of the riskiest elements of building new nuclear plants is that the long-term disposal of radioactive waste is far from resolved. The planned Yucca Mountain repository in Nevada is almost 20 years behind schedule and may never open. The projected opening date for this permanent spent fuel repository has been delayed countless times and, according to the DOE, the current target date of 2017 is a "bestachievable schedule."

A plan proposed by the Bush administration, the Global Nuclear Energy Partnership (GNEP) that would have allowed the reprocessing of spent nuclear fuel will face technical, legal, and political challenges and cannot be counted on as a realistic solution. Reprocessing leaves large amounts of waste still needing disposal, and much of the technology is unproven or undeveloped. Indeed, similar attempts to reprocess spent fuel in the past have been unsuccessful, and the DOE does not have a lifecycle cost analysis for the program.

Reprocessing would be a dangerous shift in the US global nonproliferation policy and would increase the likelihood that a terrorist could obtain material to build a nuclear bomb. It would increase the number of nuclear waste streams to be managed and secured and is the most polluting part of the nuclear fuel cycle. It would not alleviate the problem of used (spent) fuel storage on reactor sites or the need for a permanent waste repository.

US taxpayers are still paying billions of dollars each year to clean up contamination from reprocessing programs in the 1960s and 1970s for nuclear weapons at the Hanford Site (WA) and the Savannah River Site (SC), as well as the reprocessing of naval irradiated fuel at the Idaho National Laboratory (ID) and commercial reprocessing at West Valley (NY).

\section{Conclusions}

The genesis of nuclear power was the "Atoms for Peace Program" which was intended to make the public more comfortable with the horrifying destruction of the nuclear bomb. Originally, the promise was that technology would provide energy that would be "too cheap to meter." However, in the last 50 years, nuclear energy subsidies have totaled nearly 150 billion US dollars, amounting to more taxpayer dollars for R\&D than for all other energy sectors combined. In fact, nuclear power is the energy that is "too expensive to matter."

A nuclear revival is financially risky. The likelihood of large numbers of new nuclear units being built on the basis of favorable economics is unlikely. Nuclear power is not competitive today, and for nuclear power to succeed, it must achieve major cost cuts, avoid serious accidents, resolve the nuclear waste storage and disposal issues, and achieve the status of a lower carbon-emitting power source. All of these goals must be reached before nuclear power can be considered as a rational solution to our energy needs. There are risks galore, but no guarantees.

Open Access This article is distributed under the terms of the Creative Commons Attribution Noncommercial License which permits any noncommercial use, distribution, and reproduction in any medium, provided the original author(s) and source are credited. 